\title{
EL PEÓN Y LA MUERTE: EL CASO TRANSNACIONAL DE MACARIO (1960)
}

Nancy J. Membrez*

Mira que te mira Dios. Mira que te está mirando.

Mira que has de morir.

Mira no sabes cuándo.

Popular, La ronda de la muerte.

Hasta el rey muere descalzo.

(refrán)

Dime cómo mueres y te diré quién eres. Octavio Paz, El laberinto de la soledad.

RESUMEN: El artículo se propone mostrar, a partir del análisis de la película Macario (1960) dirigida por Roberto Gavaldón, el tema de la muerte y su representación en la literatura y la tradición oral en diversos contextos. Además de demostrar la existencia de ciertas variantes o conexiones con otras versiones que aluden al tema señalado.

Palabras clave: Macario, Cine mexicano, Roberto Gavaldón, Bruno Traven.

ABSTRACT: The article pretends to show, parting from the analysis of the Macario movie, the topic of death and its representation in literature and oral tradition on diverse contexts, and to proof the existence of certain variants or connections with other versions which refer to the dealt subject.

KEY WORDS: Macario, Mexican cinematography, Roberto Gavaldón, Bruno Traven.

\section{PREFACIO}

¿Existe un tema más primordial, más existencial que el del hombre y el momento en que le sorprende la muerte? Arriba cito un verso popular de

*University of Texas at San Antonio (Nancy.Membrez@utsa.edu). 
la edad media que advierte que no sabemos cuándo nos tocará morir y, como implica el refrán, el gran teatro del mundo nos depara desigualdades, pero la muerte, no. ¿No nos define la vida entera aquel momento en el que morimos? ¿Cómo seremos juzgados por los supervivientes que dejemos en la Tierra y cómo justificaremos nuestra conducta ante el Señor el día del Juicio Final? Bien dice Octavio Paz mejorando el refrán: “Dime cómo mueres y te diré quién eres". Desde que la vi por primera vez hace muchos años me fascina la película Macario, obra antigua y moderna a la vez, que nos ayuda a meditar sobre estas cuestiones metafísicas. Siendo "el peón (el más humilde de los seres humanos) y la Muerte" un motivo folclórico tan duradero y transnacional, su sorprendente desarrollo nos lleva mucho más lejos en el espacio y el tiempo de lo que parece a primera vista. Indagar en los orígenes de la historia central que se cuenta, seguir el subsiguiente desarrollo de ésta en varios géneros literarios tanto folclóricos como cultos y descubrir su manifestación en regiones lejanas tuvo todo el encanto de seguir las pistas por una novela de detectives. Quisiera aclarar, de comienzo, que las conclusiones a las que llego en este ensayo se basan en las tablas de investigación colocadas al final, que vengo recopilando de los textos analizados. Aquéllas también sirven de resumen de los argumentos del ensayo y se ilustran en el esquema final simplificado, una especie de guía. Sírvase el lector consultar las hojas analíticas si acaso pierde el hilo de la explicación.

\section{INTRODUCCIÓN}

La película Macario (1960) dirigida por Roberto Gavaldón ganó doce premios internacionales en su tiempo ${ }^{1}$ y en el contexto del cine universal entró en el panteón de las mejores películas mexicanas. En breve, es la

\footnotetext{
1 "Un diploma al mérito en el festival de Edimburgo (1960), premio de mejor actuación masculina a [Ignacio] López Tarso en el festival de San Francisco (1960), premio a la mejor fotografía en blanco y negro en el festival de Cannes (1960), premio por su participación [v.g. nominada al Oscar de la Mejor película extranjera, la primera nominación que hubo nunca para México] en las quintas académicas de Hollywood (1961),
} 
historia del famélico leñador Macario que al realizar su sueño dorado de saborear un pavo entero por sí solo se topa con la Muerte, quien le hace su compadre, convirtiéndole en curandero famoso y desengañándole de su sueño de vida a su capricho. No obstante su "mexicanidad" patente — v.g., la ambientación de la película en el México colonial dieciochesco y los ricos detalles del Día de los muertos que nos hacen pensar en los sugestivos grabados de José Guadalupe Posada- los críticos mexicanos se mostraron incomprensivos e implacables: se avergonzaban de que la película se rodase en blanco y negro, denuncia para ellos del subdesarrollo ante el mundo, abominaban de que se desperdiciase la oportunidad de retratar el colorido de los festivales, ${ }^{2}$ y aun peor, de que la película imitase descaradamente El séptimo sello de Ingmar Bergman (de 1956) con la personificación de la Muerte. Para colmo, tachaban al protagonista pobre de no criticar frontalmente a la Iglesia católica y de no promover la lucha social según su criterio político. ${ }^{3}$ Por mí, tomaron el rábano por las hojas. Macario da constancia de antecedentes tanto míticos como folclóricos que se asoman a lo largo de la película. ¿A qué tra-

premio Instituto de la ciudad de Valladolid, placa de plata y pergamino en el festival de [la VI Semana internacional de Cine religioso y de valores humanos en] Valladolid, España (1961). Cuando fue realizada, se había suspendido aquí la entrega de Arieles; si no, hubiera ganado sin duda la mayoría de su año”. En Emilio García Riera y Fernando Macotela, La guía del cine mexicano a la televisión 1919-1984, México, Patria, 1984, pp. 175-176. En otro libro García Riera agrega "el Certificado al mérito del Festival Internacional de Cine de Vancouver, Canadá, premio a la Mejor Producción Cinematográfica del Festival de Boston, diploma al mérito en el Festival de Edimburgo, premio [mejor película] del Festival de Santa Margarita Ligura, Italia, y Premio del $2^{\circ}$ festival de Nueva Delhi, India". El reclamo del estuche del video añade "Mejor película en el Festival de cine de San Sebastián y Mejor película extranjera de los premios de la Academia cinematográfica de Dinamarca". Con la concesión del premio en el segundo Festival de Cine de la India, Macario volvió a casa. "La última encarnación de Narada" habrán pensado los indios.

${ }^{2}$ Emilio García Riera, Historia documental del cine mexicano, vols., México, ERA, 1975, vol. 7, p. 201.

3 “A qué atribuir el profundo enojo con que asistimos a la exhibición de Macario? Que en este film la pantalla se vea agobiada por una abigarrada y poco dinámica fotografía, pase. Pase también la falta de ritmo y de imaginación, la poesía demasiado buscada, el carácter 
dición(es) obedece Macario en realidad? Para contestar esta pregunta primero hemos de remontarnos a la discutida cuna del cuento, La India.

\section{EL PURANA DE NARADA Y VISHNU}

Para inculcar sus doctrinas fundamentales, los hindúes cuentan con una antiquísima tradición oral popular. Los sacerdotes andaban por las calles de la India, predicando al público analfabeto en sánscrito y luego en las otras lenguas vernáculas los puranas o leyendas religiosas de su pueblo. Fundamental es el concepto religioso hindú de maya,-es decir, la manifestación material del mundo en términos de la unidad de los contrarios, como por ejemplo, masculino y femenino, vida y muerte, realidad y fantasía. Es más, con su "velo de maya" engaña al hombre el dios Vishnu, uno de los tres dioses principales del brahmanismo (v.g. Brahman, Vishnu y Shiva), el cual rige el tiempo y a veces se manifiesta con tres caras: una cara que mira al pasado, otra al presente y la última al futuro. ${ }^{5}$ Maya quiere decir "apariencia", "ilusión”, "sueño", "voluntad de Dios", "principio de la creación", una realidad tangible como lo es el mundo de los sueños hasta que el soñador se despierta. ${ }^{6}$ En uno de los

moralizante de la historia. Lo que no pasa es la moraleja: que si los hombres son humillados, todo es justo porque así lo quiere un orden superior a los hombres. [...] Macario es un buen ejemplo de ese cine 'de prestigio', pretencioso y a priori mexicano, que se realiza con vista a los festivales.” En José de la Colina, Política (primero de julio de 1960), reproducido en García Riera, op. cit., pp. 284-285. El mismo García Riera comenta: "Ni qué decir que la poetización de esa 'condición eterna [del indio pobre]' resultaba por sí misma profundamente reaccionaria y conformista, pero quizá fuera aún peor que la realización neutra de Gavaldón tendiera a justificar la apariencia de falta de ideología por la simulación de la inocencia. Como ciertos ballets y fantasías ceremoniales que pretendían reproducir la visión precortesiana de México, Macario intentaba reivindicar otra visión no occidental [sic], pura, ancestral, telúrica, etc. - para excusar la ausencia de una auténtica visión crítica, moderna, del drama indígena”. (Ibid., p. 284).

${ }^{4}$ José Vasconcelos expresa el concepto de esta forma para evitar confusiones con los mayas de México. Como no leía sánscrito, tradujo del inglés los manuscritos sobre el bramanismo.

${ }^{5}$ Doctrina hindú de suma complejidad. Véanse las obras de Shastri y Goundriaan.

${ }^{6}$ Prabhu Dutt Shastri, The doctrine of Maya in the Philosophy of the Vedanta, Londres, Luzac and Co., 1911, pp. 20 y ss. 
puranas más antiguos del Chandogya upanisad se cuenta la historia de Narada, el accidentado e ingenuo discípulo de Vishnu que sirve de vox populi preguntona en sus numerosas encarnaciones terrenales. ${ }^{7}$ En esta historia, Narada importuna a Vishnu preguntándole a éste el significado del velo de maya. Divertido, el Señor del Tiempo le pide un vaso de agua antes que se lo explique. En el acto el discípulo se desmaya y al despertarse en una aldea se acerca a la fuente (variante: a una choza) donde ve a la mujer más bella del mundo que llena un cántaro. Encantado, Narada se olvida por completo del quehacer divino que le ha llevado a la Tierra, acaba casándose con la muchacha, se distingue como señor principal de la villa, ora como músico ora como médico, tiene un hijo y vive feliz hasta que un buen día todo el pueblo perece en una inundación. Al expirar Narada, se presenta ante él Vishnu, quien le pregunta entre tierno y socarrón: "Oye. ¿Y mi vaso de agua?"8 Este cuento sirve para ilustrar al hindú que el velo de maya dicta que la vida humana sea efímera e inconsecuente, que la realidad y la fantasía sean una. Muchos de los componentes destacados de Macario se manifiestan en este cuento hindú primordial: el tema, el encuentro con la deidad, el vaso de agua, el oficio de Narada y el propio Narada, cuyo nombre significa “el que da agua”en sánscrito.

${ }^{7}$ M. Raja Reddi, Narada in Literatura, Tirupati, India, Adyar Students Xerox Centre, 1995; y Thomas Ball, "Vishnu's Maya: Filming a Legend”, Wooster Alumni Magazine, núm. 91, 4 de mayo, 1977, pp. 2-4.

${ }^{8}$ También existe una variante femenina de esta misma historia en la que una reina se cree contenta pasando la vida rodeada de sus hijos y nietos. Como esta realidad estorba su desarrollo espiritual, el sino le manda un desastre en que todos sus seres queridos perecen y ella acaba vagando sola por el campo de batalla. En ese momento Vishnu se le aparece para consolarla y mostrarle que la realidad no existe. En Teun Goudriaan, Maya Divine and Human. A study of Magic and Its Religious Foundations in Sanskrit Texts, with Particular Attention to Fragment of Vishnu's Maya Preserves in Bali, Dahli, Motilal Banarsidass, Indological Publishers and Bookseller, 1978, p. 433. Esta historia nos hace pensar en el mito griego "Niobe", la reina orgullosa castigada por los dioses del Olimpo. En Edith Hamilton, La Mythology, Boston, Little, Brown and Co., 1942, pp. 238-239. 


\section{EL COMPADRE DE CARONTE, CUENTO FOLCLÓRICO GRIEGO}

De la India a Grecia sólo hay un pequeño salto geográfico. ${ }^{9}$ Además, ya se ha establecido una ruta directa de los textos védicos (v.g. textos sagrados indostánicos) a Grecia. Desde la época posclásica hasta hoy los griegos afirman que Caronte, antiguo barquero del lago Estigia en la mitología clásica, les acecha a pie o a caballo negro y como aquél se muestra desganado en el oficio, ellos pueden llegar a regatear con él al término de su vida. ${ }^{10}$ En 1964 Lawson ${ }^{11}$ publicó el cuento folclórico griego del humilde que nombró a "Charos" (Caronte) padrino de su hijo, el único superviviente de ocho hijos. Cuando el niño tenía diez años, Caronte llevó a su compadre a una gruta llena de velas que representaban a la humanidad donde le concedió dos años más de vida y le regaló el don de verlo a los pies de la cama si un enfermo hubiera de morir. El nuevo médico se enriqueció con sus adivinaciones milagrosas tras salvar la vida de la princesa y al cabo de dos años Caronte regresó por él. La mujer del médico intentó despistar a Caronte haciendo girar la cama, sin éxito. Cumpliendo con su deber, Caronte le agarró y le arrancó el alma. Yo postulo que los griegos adaptaron la leyenda india cambiando la deidad, elaborando el juego de la cama, y agregando el motivo de la gruta de las velas de la humanidad, puesto que las referencias a las cuevas y a los infiernos de Hades abundan en la mitología griega (y los escritos de

${ }^{9}$ Sin embargo, hay quien afirma que nunca hubo transmisión alguna de textos indostánicos a Grecia por razones oscuras. Véase Giuseppe Cocchiara, The History of Folklore in Europe, trad. de John N. Mc Daniel, Filadelfia, Institute for the Study of Human Issues, 1981 [1952 en italiano]. Todavía hay controversia entre los folcloristas. Por ejemplo, parece no haber vínculo entre los cuentos indostánticos y las fábulas de Esopo.

10 "The narratives [oral histories collected by the authors] reflect the effort to humanize death, to conceive of it in familiar terms, to make it subject for ordinary thinking. So it is that the villagers come to think of death, as concrete and personal, as Charon himself, with whom one can speak, and if needs be, beg a boon”. En Richard y Eva Blum, The Dangerous Hour: the Love of Crisis and Mystery in Rural Greece, Londres, Chatto and Loindus, 1970, p. 223.

${ }^{11}$ John Cuthbert Lawson, Modern Greek Folklore and Ancient Greek Religion. A Study in Survivals, Nueva York, University Books, 1964, pp. 102-103. 
Platón) y está bien establecida la metáfora de la kantela [candela] para significar la vida de una persona. ${ }^{12}$

Sospecho que también existe un nexo literario árabe, ${ }^{13}$ el cual puede representar otro camino para la transmisión del purana a Europa porque otra colección de cuentos indios, los de la Panchatantra, fue traducida al persa, del persa al árabe, del árabe al latín, y del latín al alemán en el siglo XIII. ${ }^{14}$

\section{EL SEÑOR PADRINO, CUENTO FOLCLÓRICO ALEMÁN}

De Grecia a Alemania habrá habido otro brinco geográfico. Ya se ha comprobado definitivamente que un cuento griego parecido tomó esa ruta en la Edad Media, ${ }^{15}$ incluso puede ser variante del mismo, ya que sólo hay un paso entre el deseo de sobrevivir y el de querer vivir para siempre. En el segundo cuento griego, un ladrón pactó con el Diablo para ser inmortal y después éste desgastó cuarenta pares de sandalias persiguiéndole para ahorcarle. Es menester apuntar que en el folclore es bien frecuente que los personajes evolucionen o cambien totalmente de identidad, ${ }^{16}$ por ejemplo, las variantes acomodan el intercambio de la Muerte por el Diablo, o la virgen María por la Muerte. Tampoco hemos de perder

12 "When our days end, when the olive oil finishes in our candles, then we must leave this earth". En Blum, op. cit., p. 44.

${ }^{13}$ La única referencia literaria que he encontrado es el cuento árabe que sirve de epígrafe a Appointment in Samarra, de Somerset Maugham. Dice así: un día mi criado me interpeló y aterrado me contó que en la plaza acababa de toparse con la Muerte, quien le había señalado con un gesto amenazante. Mi criado me suplicó: "Présteme un caballo, mi amo, para que me fugue a Samarra donde la Muerte no me hallará”. Yo le presté el caballo y mi sirviente salió volando para Samarra. En ese momento me apareció la Muerte. Le interrogué por qué había amenazado a mi criado en la plaza, y la Muerte me replicó asombrada: "Yo no le amenacé. Sólo me sorprendió que estuviera aquí, ya que nosotros hemos quedado para esta noche en Samarra".

${ }^{14}$ Según Theodor Benfey, erudito del sánscrito del siglo XIX. Citado por Joseph Campbell "Epilogo a los Grimm's Fairy", 1944, p. 846, en su postdata a los cuentos de los Grimm.

${ }^{15}$ George A. Megas [ed.], Folktales of Greece, trad. de Helen Colaclides, Chicago, University of Chicago Press, 1970, p. 44.

${ }^{16}$ Vladimir Propp, Morphology of the Folktale, 2a ed., Austin, University of Texas, 1968 [1928 ed. Rusa]. 
de vista la cristianización por la que pasaron todas las leyendas antiguas en los últimos dos milenios. Esta misma historia, por lo tanto, vuelve a nacer en Alemania en la Edad Media con el título "Die Schuhe des Teufels" con moraleja cristiana ${ }^{17}$ en la que un campesino, tras consultar a una bruja, consiguió la inmortalidad al no desmontarse nunca de su caballo. Después de varios siglos el jinete vio una figura encapuchada que intentaba reparar una carreta. El jinete se apiadó del carretero, se desmontó para ayudarle y le preguntó por qué llevaba una carreta llena de zapatos desgastados. Entonces le contestó que la Muerte ingrata le había perseguido a lo largo de los siglos y ahora lo tenía en sus garras para llevárselo. ${ }^{18}$ Aquí no andamos lejos de las posteriores figuras literarias cultas Fausto y su primo español, don Juan Tenorio.

En Alemania los hermanos Jacob y Wilhelm Grimm, los padres de los estudios folclóricos modernos, ${ }^{19}$ publicaron en 1819 su recopilación que abarcaba dos cuentos mágicos, "Der Herr Gevatter" (núm. 42) y "Der Gevatter Tod" (núm. 44), en los que se reparten los motivos folclóricos del Compadre de la Muerte griego que vengo comentando. Las ver-

${ }^{17}$ Megas, op. cit., p. 44.

${ }^{18}$ Se ha editado una versión infantil de esta historia en Inglaterra en Selina Hastings [adapt.], The Man Who Wanted to Live Forever, ils. de Reg Cartwright, Londres, Walker Books, 1988.

${ }^{19} \mathrm{El}$ estudio serio del folclore arranca con el descubrimiento de las Américas que obliga a los europeos a considerar (y a comparar) sus propias tradiciones con las ajenas. De ahí que éstos recopilen romanceros y antologías de leyendas (véase Cocchiara, op. cit.). Los hermanos Grimm, entre los enciclopedistas del siglo XVIII y los románticos del XIX, puntualizan el proceso de recolección y recuperación siguiendo (para bien o para mal) su propio criterio, o sea, el pulimiento de textos populares. John Ellis, One Fairy Story Many, Chicago, University of Chicago, 1983. En el siglo xx, los folcloristas Antti Aarne, Stith Thompson y Vladmir Propp los clasificarán según su tipología. Propp propone una serie de unidades para analizar despasionadamente un cuento folclórico. Según sus preceptos, podemos apreciar un patrón popular en todos los cuentos folclóricos, y la película Macario no será menos. Las categorías y números son de Propp. He aquí una muestra:

1. La marcha. Después de recoger leña, Macario la entrega a domicilio.

2. Prohibición o sugerencia. Piensa en su propia muerte cuando le recuerda el cerero que es el Día de los muertos y que nunca tendrá un guajolote para él sólo. Se subraya esta situación en el sueño de los fantoches en que Macario se pinta titiritero. 
siones alemanas añaden los elementos cristianos del trío celestial del Diablo, Dios y la Muerte y desarrollan otros detalles nuevos. Tras el éxito de esta colección, los cuentos se vuelven a editar y se traducen a todas las lenguas europeas.

\section{EL HARTÓN Y LA MUERTE, CUENTO FOLCLÓRICO MEXICANO}

Desde Alemania, postulo que la historia indo-greco-alemana saltó a España mediante la traducción al castellano y de ahí a México, su antigua colonia. Habiendo apuntado Camarena variantes modernas del cuento en todas las lenguas de la Península ibérica, sería lógico concluir que la historia se originase en España, ya que en notables obras literarias de la Edad Media la Muerte se personifica, v.g., "La danza de la muerte", el romance "El enamorado y la Muerte", y por el sentimiento del memento mori, "La ronda de la muerte" (que cito al principio de este estudio), y las "Coplas por la muerte de su padre", de Jorge Manrique. Sin embargo, en su minucioso catálogo de motivos folclóricos de la España medieval, Goldberg no apunta ninguno que se parezca al "Compadre o ahijado de la Muerte",

3. Desobediencia. Macario quiere comerse un pavo por sí solo sin compartirlo con nadie. Con la ayuda de su mujer, se larga al bosque a llevar a cabo su propósito.

4. El antagonista intenta informarse acerca del protagonista. En este caso se multiplican a tres, número común en el folclore. El diablo, nuestro Señor y la Muerte importunan a Macario.

5. El antagonista interroga a su víctima. Macario responde a la pregunta “¿Por qué compartiste el pavo conmigo y no con los otros intrusos?"

6. El antagonista intenta engañar a la víctima. El diablo recrea el "Tibi dabo" de la Biblia, Dios le pide un gesto y la Muerte se detiene mientras come la mitad del guajolote. 7. La víctima se deja decepcionar y ayuda a su interlocutor sin querer. Efectivamente, Macario acepta el agua milagrosa, un agente mágico, lo cual resulta en el "sueño" de vida de Macario.

8. El antagonista hace daño a uno de los familiares de la víctima. El hijo de Macario se ahoga y Macario le salva. Macario cura a la esposa de don Ramiro, el hombre más rico del pueblo cuya ofrenda del día de los muertos ha sido la más espectacular. Luego le traiciona el médico denunciándole a la Inquisición.

a. El protagonista carece de algo o desea algo inalcanzable. Macario arma el negocio con don Ramiro. Toda su familia come pavo. Mejora su vida material, etcétera. 
lo cual me hace pensar que la historia no fuese introducida en España hasta el siglo XIX. ${ }^{20}$ Por lo mismo descarto un origen precolombino ya que tampoco consta en la literatura indígena que sobrevivió a la Conquista. Los ejemplares en español o se exportaron al Nuevo Mundo o se volvieron a imprimir en México hacia 1850 donde en seguida los cuentos pasaron a la tradición oral. En un siglo en que Alemania se decía la capital de los estudios filosóficos, se proponían los cuentos de los Grimm para la instrucción ideal de niños, asegurando indirectamente la supervivencia de la transmisión oral de los mismos. Cuando Wheeler los recogió en su estudio de 1943, el pueblo mexicano ya relataba "El hartón y la Muerte" intercalado entre los "Tres puerquitos" y "Pulgarcito" como si éstos fuesen indígenas, ${ }^{21}$ testigo el propio actor mexicano Ignacio López Tarso (D.F. 1925-), el que protagoniza Macario, quien recuerda que: "antes del cuento de Traven y del de Grimm incluso, la conocí por mi papá, que nos

${ }^{20}$ Sólo he encontrado una fuente que afirma que existe una leyenda medieval de "la calavera que habla", de origen quizá bretón. En esa historia referida por Américo Castro (que a su vez dice citar un romance que descubriera Ramón Menéndez Pidal), un hombre da un puntapié a una calavera que yace medio enterrada en el camino. Como lo hace adrede, la calavera se queja de tamaña profanación, el culpable le convida a comer y luego la calavera le revela un valle de antorchas para recordarle su mortalidad. Como en los otros casos que vengo citando en este estudio, el problema estriba en el año de publicación del ensayo de Américo Castro, "La leyenda de don Juan en la literatura española”, en Gregorio Marañón, Cinco ensayos sobre don Juan, Valencia, Editorial "Esperia", 1930?, pp. 13-14: los años veinte del siglo xx, o sea, suficiente tiempo para contar con la penetración de los cuentos de los hermanos Grimm y consecuente "contaminación" de las leyendas locales. Ninguna otra fuente que consulté menciona esta presunta "leyenda medieval" en sus catálogos de motivos folclóricos de España. Sin embargo, tampoco es del todo descartable que el gran filólogo español Menéndez Pidal recogiera algún romance medieval español de esas características.

${ }^{21}$ El erudito Guthke, biógrafo de B. Traven, buscó la leyenda del hartón en una enciclopedia de folclore mexicano publicado en inglés en EEUU en 1947 para comprobar que la leyenda mexicana precediese al cuento de Traven. Por lo visto, Guthke no descubrió que Wheeler ya identificara variantes mexicanas de la misma leyenda en 1943. Sea como fuere, su premisa es falsa. Guthke, siendo germanista, no cae en la cuenta de que no se trate de que el cuento folclórico predate al de Traven, sino que se compruebe que predate a los hermanos Grimm. Media más de cien años entre la publicación de los cuentos recopilados por los hermanos Grimm en 1819 y sus subsiguientes tra- 
la contaba a mis hermanos y a mí de chiquillos, 'El ahijado de la muerte' se llamaba y según él era un cuento popular". ${ }^{22}$ A pesar de la anomalía cultural del campesino mexicano que teme la muerte, el cual contradice todo el estudio de Octavio Paz que dicta que al mexicano "no le importa la muerte porque no le importa la vida", los mexicanos parecen aceptar la caracterización del hartón.

Aquellos primeros traductores que vertieron el cuento alemán al castellano seguramente afrontaron otra anomalía aún más abrumadora que presentaba la traducción: en todas las lenguas germánicas la muerte es "masculina", testigo su encarnación más reciente Meet Joe Black (Brest, 1998). ${ }^{23}$ En cambio, en todas las lenguas romances, la muerte y sus eufemismos son "femeninos": la Parca, la Segadora de almas, Ella, y en México, la Catrina, con unas escasas caracterizaciones masculinas: el ‘Amargo' del folclore andaluz, y el Mal pálido. ${ }^{24}$ Se convierten, por lo tanto,

ducciones y la publicación del cuento de Traven en 1950. Que los cuentos de los Grimm se dieran a conocer en castellano por medios folclóricos o cultos es indiscutible ya que Wheeler y otros han recogido e intercalado cuentos folclóricos de los Grimm como si fuesen originales de la tradición oral de México. Ahí está el detalle que da al traste con la tesis de Guthke. Sólo acertó éste al afirmar que Traven se valió de otras fuentes que combinó con los cuentos alemanes de Grimm para crear "Der dritte Gast" en 1950.

${ }^{22}$ Susana López Aranda, El cine de Ignacio López Tarso, México, Universidad de Guadalajara, 1997, p. 56.

${ }^{23}$ He aquí otras películas de Hollywood en que la Muerte masculina protagoniza un papel: On Borrowed Time (Bucquet, 1939), que se basa en "The Pardoner's Tale", de Chaucer que a su vez se deriva del motivo folclórico 330A, en el que la Muerte se atrapa en un árbol sin poder bajar (Thompson, op. cit., pp. 45-46); Death Takes a Holiday (1934), y las parodias de El séptimo sello (Bergmann, 1956) que aparecen en Bob and Ted's Bogus Adventure (Hewitt, 1991) y Last Action Hero (McTiernan, 1993) con Arnold Schwarzenegger.

También cabe mencionar por el tema del "sueño de la vida" el cortometraje francés $A n O c$ currence at Owl Creek Bridge (1962) basado en un cuento de Ambrose Bierce, quien ganó un Oscar, en el cual se narra la historia de un reo condenado a la horca que imagina otra vida en que se escapa y vive feliz con su familia - hasta que la horca le rompe el pescuezo. Otras películas: Groundhog Day (Ramis, 1993) y hasta The Matrix (Wachowski, 1999).

${ }^{24}$ Sólo he visto este término en un artículo de Concha Espina publicado en los años veinte. El dibujo de Manuel Bujados que acompaña la poesía, sin embargo, retrata a la Muerte femenina con guadaña. 
"Der Herr Gevatter" en "El señor padrino" (porque en esta versión el padrino es el Diablo) y "Der Gevatter Tod" en la Muerte madrina en lugar de la Muerte padrina. Volveremos a este dilema lingüístico en seguida.

\section{"MACARIO", CUENTO ALEMÁN, NORTEAMERICANO Y MEXICANO DE B. TRAVEN, EL MISTERIOSO}

Un siglo después de la primera edición de los cuentos de Grimm, el misterioso anarquista yanqui-alemán conocido por B. Traven (1882-1969) se fugó a México donde comenzó una distinguida carrera literaria a larga distancia (véanse los estudios de Arnold, Machinek, Richter y Baumann). En 1950 publicó en alemán "Der dritte Gast" [El tercer huésped] al que incorporó los cuentos 42 y 44 de Grimm que ya conocía en su juventud y las variantes populares mexicanas que tal vez oyera contar, ${ }^{25}$ mezclándolos con el color local mexicano y con elementos históricos (época virreinal; referencia a la Inquisición). Además, por primera vez le da nombre al protagonista, tal vez pensando en el anacoreta egipcio del siglo IV, San Macario el grande (fiesta el 19 de enero), el que afianzó la salvación de otros ermitaños, vecinos suyos del desierto, a quienes tentaba el Diablo con frascos de bebidas de diferentes sabores y aromas. ${ }^{26}$ Macario se caracteriza por primera vez como leñador, valiéndose Traven de la metáfora bíblica del hombre/árbol, flor de un día, para subrayar la vida efímera del hombre. A mediados de los cincuenta Traven, el escritor elusivo que usaba una treintena de seudónimos para despistar a sus imaginados perseguidores, publicó el mismo cuento en inglés, el cual ganó un premio literario en Nueva York, y luego su esposa Rosa Elena Luján lo tradujo al castellano, ${ }^{27}$ manteniendo la caracterización masculina del antagonista

${ }^{25}$ Gabriel Figueroa no sólo colaboró con Traven en esta película sino que eran amigos. En su autobiografía Figueroa relata cómo Traven le enseñó al hijo de Figueroa a cantar canciones infantiles en alemán. En Alberto Isaac, Conversaciones con Gabriel Figueroa, Guadalajara, Universidad de Guadalajara, 1933.

26 "Saint Macarius the Great". En Catholic Information, Network Internet, 2000.

${ }^{27}$ El que Traven no dominara el castellano se manifiesta plenamente en la versión original en inglés de El tesoro de la Sierra Madre, The Treasure of the Sierra Madre, en 
germánico y esquivando el dilema lingüístico mediante el uso de los eufemismos "el interlocutor", "el visitante", "el viajero", "el intruso", “el convidado", "el forastero", "el caminante" y otros.

\section{"MACARio", AUTO SACRAMENTAl MEXiCANo, GUión DE EMilio CARBA- Llido, Roberto GaVAldón y "PedRo de URdemales"}

El celebrado dramaturgo mexicano Emilio Carballido (1925-), el director Roberto Gavaldón (1909-1986) y "Pedro de Urdemales" fundamentaron el guión de Macario en el cuento de Traven, en los cuentos de Grimm, y en variantes locales de éstos, ampliando y redondeando los detalles más superficiales, por ejemplo, la ambientación de la obra en el Día de los muertos, el metateatro de la pesadilla de Macario, el encuentro con el trío sobrenatural, el negocio con don Ramiro, y todo el proceso inquisitorial. "Pedro de Urdemales" es un seudónimo que se deriva de la figura folclórica mexicana de mil peripecias — Urdemales será una corrupción de "Urbe de males"- el cual puede indicar las raíces folclóricas del guión o tal vez encubrir el nombre del borroso B. Traven. ${ }^{28}$ Es indudable que los guionistas Carballido y Gavaldón también conocían los cuentos de Grimm, ya que una de las escenas más destacadas de la película, la de la cueva de velas, no aparece en el cuento de Traven sino en el anterior. ${ }^{29}$ Eligieron, sin embargo, conservar la Muerte "masculina" del escritor germánico Traven, ya que la Muerte "madrina" habría supuesto otra dinámica entre los personajes. Por un lado, de esta manera Macario se encara con un famélico peón con quien puede compararse y de quien puede hacerse compadre. Por otro lado, la imagen de la Muerte "masculina” rompe con la tradición hispánica y puede extrañar al público.

la que se intercalan algunas frases que se suponen en español. Son en realidad barbarismos de extranjero. Por ejemplo, dice "matrícula" en lugar de "madre". No hubo versión "original” en alemán.

${ }^{28}$ Y si no es Traven, ¿por qué administra su viuda el manuscrito del guión?

${ }^{29}$ Un crítico francés cree que se trata de una escena copiada a la película muda alemana Las tres luces (1921), de Fritz Lang. Citado por García Riera, op. cit., p. 104. 
Sin embargo, es curioso notar que al indio bilingüe mexicano tal vez no le importe el sexo de la Muerte, puesto que en náhuatl y en maya no existe la distinción de género. ${ }^{30}$ La palabra en maya para la muerte es "cimil" y en náhuatl miquilizti. Resulta sugestivo que en náhuatl no sólo exista una palabra para "muerto" (miczui) sino una palabra especial para un "hombre muerto de hambre" (teociuhqui o apizmiquini), testigo de la frecuencia de la muerte de esta índole entre los indios. ${ }^{31}$ Desde el estreno de la película, Macario ha entrado en el folclore local donde antes se desconocía "El hartón y la muerte", en Chiapas, por ejemplo, y los cuentistas de esa zona aseguran que es una fábula del Nuevo Mundo, tal vez precolombina. ${ }^{32}$

Viene a cuento que Emilio Carballido - oriundo de Veracruz (una de las regiones en que se ha apuntado una versión oral de "El hartón y la muerte" $)^{33}$ y ferviente discípulo de Calderón de la Barca ${ }^{34}$ — acabase de

30 “En la lengua náhuatl, no existe el género. Únicamente se emplea el término cihuatl (mujer) para lo femenino y oquichtli (macho) para determinar seres humanos, animales, plantas y objetos inanimados". En María Anzures Rionda, Lengua y cultura náhuatl, México, Contraste, 1996, p. 60.

${ }^{31}$ Véase ibid.; Alonso de Molina, Vocabulario en lengua castellana y mexicana y mexicana y castellana, $2^{a}$ ed., México, Porrúa, 1977 [c. 1555-1571]; M. Zavala y A. Medina, Vocabulario español-maya, Mérida, Yucatán, 1975 [c. 1898].

32 "Gavaldón establishes such a strong link between the mythical history of ancient and contemporary Mexico that some years later, an anthropologist researching the legends of southern Mexico discovered that the plot of the film had been totally assimilated into the mythology of the region (where the film was widely distributed) as an ancient myth”. Ariel Zúñiga, “Roberto Gavaldón”, en Paulo Antonio Paranaguá [recop.], Mexican Cinema, trad. de Ana M. López, Londres, British Film Institute, 1975, p. 200.

Hasta los eruditos se equivocan. Miller dice, hablando del cuento de Traven, que "In his long story, 'Macario', Traven gives a New World twist to the old Faustian theme; the hungry Macario, who sometimes earns as much as two bits a day at woodcutting, is a universal figure confronting Old Man Death. The Mexican film of Macario won ten (sic) international film awards, and the story is one of the finest New World folk tales in our literature". En Charles Miller, "Introduction" a B. Traven, The Night Visitor and Other Stoires, Nueva York, Hilland Wang, 1973, p. XIII.

${ }^{33}$ Carballido nació en 1925 en Córdoba, Veracruz, pero sus padres le llevaron a México cuando tenía un año. No volvió hasta 1938, año decisivo para su formación. En Margaret Sayers Peden, Emilio Carballido, Boston, Twayne Publishers, 1980.

${ }^{34}$ Joseph F. Vélez, "Una entrevista con Emilio Carballido", Latin American Theater Review, núm. 7.1, 1973, pp. 17-24. 
estrenar el segundo de sus propios autos sacramentales en tres jornadas, La hebra de oro, en 1956 (publicado en 1957) (35 $^{35}$ cuando se puso a trabajar en el guión de Macario con Roberto Gavaldón y "Pedro de Urdemales". Aunque el contexto es un melodrama burgués, no deja de ser singular que en la pieza haya una gruta subterránea con un manantial que coincide con una de las imágenes de los hermanos Grimm y su representación en la película Macario (no aparece en el cuento de Traven). "El hombre," un mago cuyo avión ha estrellado ha entrado en casa de los principales por la puerta supuestamente candada de la gruta. Desorientado y desmemoriado por el accidente comenta a la familia asombrada por su aparición repentina:

La realidad se escapa. ¿No ha visto qué lógico parece todo en nuestros sueños? Y la memoria cree lo que más le conviene. Ya, perdón, ya empieza a trabajar la memoria. De repente a un reloj le dan cuerda: estaba fuera del tiempo y las agujas tardan en el sitio correspondiente a una determinada posición de la tierra y del sol y del sitio en que el reloj se encuentra dentro de círculos incandescentes y ruedas cósmicas y explosiones y leyes de gravedad y espirales infinitas; la maraña de que le hablaba, la telaraña de la materia, ¿se acuerda? La memoria es la distancia más corta entre el yo y el tiempo, y ahora la siento volver lentamente. [...] ¿No es milagroso? Todos recordamos lo imaginado, lo leído, lo deseado, lo que nos cae sobre los sentidos desde fuera, y todo pasa aquí a ocupar su sitio. ¿Qué es lo propio? ¿Qué es lo ajeno? Misterio. Lo lamento, tendré que usar el automatismo y la incoherencia. Es una receta que puedo darles: Cuando se sientan perder o hundir, tóquense, pálpense (lo hace) y reciten sus recuerdos en oración, porque somos eso, eso nos suelda, nos une: cuerpo y recuerdos. Ya está. Recuerdo, recuerdo. Pero falta el nombre. El nombre es como un lazo. ${ }^{36}$

Dada esta huella de Carballido en el guión, Macario cabe perfectamente como auto sacramental calderoniano porque muestra la redención del personaje (aunque muere inconfeso), cuyo sacramento es el guajolote

${ }^{35}$ El primero fue Auto sacramental de la zona intermedia (1951) y el tercero El día que se soltaron los leones (1960). Véase el estudio de Eugene Skinner, "Carballido: temática y forma de tres autos", Latin American Theater Review, núm. 3.1, 1969, pp. 37-47.

${ }^{36}$ Jornada II, escena 4. Las cursivas son mías. 
que hace las veces de hostia. "El auto de Macario", si así puede llamarse, se enlaza con la verdadera historia del virreinato porque el teatro evangélico fue arma imperial para convertir e instruir a los nuevos cristianos de la Nueva España. ${ }^{37}$ (De ahí quizá que se sulfuraran tanto los críticos mexicanos en el momento del estreno de la película.)

Macario también entronca perfectamente bien con el Realismo mágico latinoamericano que venía produciéndose en la literatura de los cincuenta, época en que Carballido y Gavaldón tramaban el guión. En particular, Juan Rulfo publicó El llano en llamas (1953), cuyo primer cuento se titula "Macario", y a pesar de no conformarse al estilo ni de Grimm ni de Traven ni del guión, hay coincidencias notables. Este nuevo Macario, narrador del cuento en primera persona, anda tan hambriento como nuestro hartón.

Mi madrina no me regaña porque me vea comiéndome las flores de su obelisco, o sus arrayanes, o sus granadas. Ella sabe lo entrado en ganas de comer que estoy siempre. Ella sabe que no se me acaba el hambre. Que no me ajusta ninguna comida para llenar mis tripas aunque ande a cada rato pellizcando aquí y allá cosas de comer. Ella sabe me como el garbanzo remojado que le doy a los puercos gordos y el maíz seco que le doy a los puercos flacos. Así que ella ya sabe con cuánta hambre ando desde que me amanece hasta que me anochece. Y mientras encuentre de comer aquí en esta casa, aquí me estaré. Porque yo creo que el día en que deje de comer me voy a morir, y entonces me iré con toda seguridad derechito al infierno. $\mathrm{Y}$ de allí ya no me sacará nadie, ni Felipa [amante de Macario que ha prometido interceder por él ante el Señor], aunque sea tan buena conmigo, ni el escapulario que me regaló mi madrina y que traigo enredado en el pescuezo. ${ }^{38}$

Carballido conocería este cuento y tal vez ampliase el carácter del Macario fílmico pensando en aquellas palabras de Rulfo. ${ }^{39}$

${ }^{37}$ Véase Adam Versényi, "Getting under the Aztec Skin: Evangelical Theatre in the New World”, New Theater Quarterly, núm. 5.19, 1989, pp. 217-226.

${ }^{38}$ Juan Rulfo, El llano en llamas, México, FCE, 1953, p. 12. Las cursivas son mías.

${ }^{39}$ El vínculo con el Realismo mágico nos recuerda 'El milagro secreto', cuento de Jorge Luis Borges, en el que un condenado a muerte vive todo un año ante el piquete para 
Peden nos asegura que el psicoanálisis de los personajes y el humor son típicos de los dramas de Carballido ${ }^{40}$ y yo postulo que la sensibilidad literaria y escénica de este guionista nos proporciona los mejores momentos cómicos de su hábil adaptación y renovación, a pesar de que Zúñiga afirme en su biografía que Gavaldón fuese el guionista principal. ${ }^{41}$ Por ejemplo, cuando Macario cuenta a la Muerte por qué rechazó la petición del Diablo charro y la de Nuestro Señor peregrino; o cuando cura enfermos que parecen momias con la Muerte sonriente a su lado; o cuando contesta las preguntas del Santo Tribunal sobre el acercamiento de la muerte al moribundo (“¿En qué lo notas? ¿En los ojos?” Macario: “En los pies y en la cabeza, señor" [100]), o cuando se somete a la prueba inquisitorial para determinar cuál de los prisioneros ha de morir (resulta ser el verdugo mismo), nosotros los espectadores nos reímos de la autoridad con él, ya que se manifiesta la socarronería del campesino ante una fuerza superior, típica de los cuentos folclóricos.

\section{MACARIO, PELÍCULA MEXICANA ${ }^{42}$}

La película Macario, rodada en cinco semanas en Taxco, Zempoala y Cacahuamilpa, ${ }^{43}$ representa la culminación de la historia que vengo contando desde sus orígenes en el subcontinente. Al director de fotografía Gabriel Fi-

terminar de escribir su libro y arreglar sus asuntos en los segundos suspendidos que dura el vuelo de las balas que han de matarle.

40 "Character is the saliente feature of Carb29haracters, the forces that destroy them and the epiphanies that illuminate them" (160). Y después: "Humor appears almost exclusively in Carballido's drama" (166).

${ }^{41}$ El actor López Tarso destaca la maestría técnica del cineasta autodidacta Gavaldón pero no menciona su aportación al guión. López Aranda, op. cit., p. 56.

${ }^{42}$ Macario no fue la única colaboración del guionista Carballido, director Roberto Gavaldón, director de fotografía Gabriel Figueroa y la montadora Gloria Schoemann, aunque sí fue la primera. En Ariel Zúñiga, Vasos comunicantes en la obra de Roberto Gavaldón, México, El Equilibrista, 1990, pp.360-361. La otra fue La rosa blanca (1961) que también utilizó un cuento de Traven para fundamentar el guión. Sería un proyecto interesante contrastar las dos películas.

${ }^{43}$ García Riera, op. cit., p. 284. 
gueroa (1907-1997), padre de la cinematografía mexicana, le debemos la belleza nítida y duradera de la imagen en blanco y negro que fue perfecta para subrayar todos los detalles de esta historia y darle un toque mítico.

Si la mexicanidad visual de la película se manifiesta en el uso de los esqueletos y ofrendas, la auditiva se registra primero en la "Ronda del Milano" y luego en el "Corrido de Macario". Todos estos elementos seguramente contribuyeron a la difusión popular de Macario en México después de su estreno. Durante el rodaje los dibujos animados que se programaban en el guión para la pesadilla de Macario pasaron a ser marionetas de esqueletos y la "Ronda del Milano" y el "Corrido de Macario", que sólo se describían en las acotaciones del guión, se concretaron.

Los niños reproducen en su juego diario el mundo adulto que les rodea. En este caso, en unos planos, los cuales hacen contrapunto a la acción principal de la mujer de Macario que esconde el guajolote robado, los hijos de Macario y sus amigos juegan al "Milano", un auténtico coro infantil de sabor medieval compuesto de coplas de doce sílabas de rima consonante (con inconsistencias populares). ${ }^{44}$

"Cantan haciendo ronda:

1) Mariquita la de atrás que vaya a ver (12) a

si vive o muere pa' echarnos a correr.

(12) a

¡Está muerto! ¡Córranle! [hablado].

[Un niño sale del círculo para tocar al otro niño. Todos huyen gritando cuando aquél dice 'Está muerto'.]

${ }^{44}$ Habiendo pasado su niñez en Chicago, Traven no podría sino acoplar la "Ronda del Milano" con el coro infantil inglés que también se canta haciendo un círculo. "Ring around the rosies, a pocket full of posies. Ashes, ashes. We all fall down". Este coro data de la época de la peste negra en Europa y pasó a EEUU durante la era colonial. En la actualidad los niños no suelen reconocer que con este coro recrean el drama de la vida y la muerte. En cambio, en la "Ronda del Milano", no existe tal ambigüedad. 
2) Mariquita la de atrás...

¡Está caliente! [hablado.] [El mismo juego.]

3) Vamos a la huerta de Don Porfil [cantado.] (11) b

a ver a Milano comiendo perejil.

4) Milano no está aquí; está en su vergel abriendo la rosa, cerrando el clavel'. ${ }^{45}$

¡Está muerto! ¡Corran! [hablado]

La niña mayor le pregunta al niño que está en el centro del círculo:

¿¿Con quién te vas? ¿Con el ángel o con el Diablo?'

El niño responde: 'Con el Diablo'.

El Diablo lo elige y se lo lleva". ${ }^{46}$

Estos planos, aparentemente de colocación accidental, prefiguran el encuentro de Macario con el trío sobrenatural, la caída fatal de uno de los niños al pozo abandonado del mismo sitio donde juegan, y la misma suerte de Macario.

Aunque es totalmente nuevo, el "Corrido de Macario" es auténtico según su forma porque se trata de un romance popular de ocho sílabas, de rima consonante en abab en la primera estrofa y øAøA en las otras. Los primeros dos versos son una fórmula para pedir que los espectadores "abran los ojos y preparen las orejas (sic: el oído)". He aquí el corrido cuya letra no aparece en el guión.

${ }^{45}$ En el guión termina el verso de otra forma: "buscando la rosa/cortando el clavel". Como es coro popular es natural que haya variantes.

${ }^{46}$ Letra de la película Macario (1960), Dir. Roberto Gavaldón, Guión de Roberto Gavaldón, Emilio Carballido y "Pedro de Urdemalas" [B. Traven?]; desde "Milano no está aquí” figura en el guión, pp. 49-50. 
El corrido de Macario

Abran los ojos, señores, a

y preparen las orejas: b

Que se acaban los dolores, a

las dolencias y las quejas. (bis) b

2) Vienen volando en carrozas $\varnothing$

porque no hay quien no se apure c

y quieren ganar lugares $\quad \varnothing$

pa' que Macario los cure. (bis) c

3) Ha curado a muchos ricos $\varnothing$

pero cuando Dios no quiere d

de nada sirve el dinero $\varnothing$

también el rico se muere. (bis) d

4) Sale ganando el doctor $\varnothing$

y también el carpintero. e

La viuda llora afligida; $\quad \varnothing$

Se va a quedar sin dinero. (bis) e

5) Macario no lo permite $\varnothing$

porque es un hombre derecho. $\mathrm{f}$

Se lo devuelve a la viuda, $\quad \varnothing$

lo cual está muy bien hecho. (bis) f

El corrido es aún más subversivo dentro de la película en su función de vox populi y periódico popular porque nos asegura que Macario sí se portó bien al usar el don que le regaló la Muerte en contraste con la acusación posterior de ésta de que lo desperdiciara para enriquecerse. Hasta uno de los versos contradice la acción principal: el médico cree que no se benefició del negocio de Macario, pero el pueblo insiste en que sí. Esta secuencia nos muestra en una elipsis de dos minutos cómo Macario se hizo médico renombrado sin aprovecharse ni del pobre ni del rico. 
Además, algo le habrá sonado al público mexicano puesto que existe un corrido que habla de otro Macario, héroe de la Revolución. ${ }^{47}$ Incluso, puede que la introducción del corrido en el guión influyera en la decisión de ambientar la película en el siglo XVIII en lugar del XVI o del XVII (como en el cuento de Traven) porque la Real Academia Española de la Lengua sólo reconoció la voz "corrido" en 1729 y realmente no cuajó en su forma presente hasta $1870 .{ }^{48}$ Sospecho que Carballido anduvo en el ajuste de las fechas para evitar un anacronismo.

Si comparamos el guión con la película, notamos que el director Roberto Gavaldón optó por revisar y abreviar el final que resultaba largo y complicado ya que intentaba seguir el desenlace del "Gevatter Tod" al pie de la letra. ${ }^{49}$ Acertó al hacer que Macario no salvase al hijo del virrey y que al salir de la cueva que no mostrase su vela chiquita que llevaba en la mano, sino que volviese al momento de su encanto sobrenatural, al momento en que muriera de hambre.

\section{CONCLUSIÓN}

En este ensayo he contado cuentos y más cuentos que vienen siendo uno solo. El pobre reconoce en la Muerte a un familiar a quien respeta por no favorecer a los ricos e igualar a todos. Al fin y al cabo, es la Muerte - caprichosa, cruel y a ratos compasiva - quien siempre ríe al último. Todas las culturas que han tomado a Narada-Macario por cuento suyo, reconocen el sentimiento barroco de "la vida es sueño" y la fatalidad del "ni más ni menos" (que se retrata en Finis gloria mundi, cuadro de Juan de Valdés Leal), ${ }^{50}$ ideas que conmemoran el Día de los difuntos, y que

\footnotetext{
${ }^{47}$ Merle Simmons, The Mexican Corrido as a Source for Interpretive Study of Modern Mexico (1870-1950), Bloomington, Indiana University Press, 1957.

${ }^{48}$ Loc. cit.

${ }^{49}$ Véase Leo L. Barrow y Robert H. Hammond, Macario. A Textbook Based on a Filmscript by B. Traven [¿sic?], Riverside, CA, J. B. Blanchard Press, 1973, pp. 119-126.

${ }^{50}$ Reproducido en Janis Tomlinson, From El Greco to Goya. Painting in Spain (15611828), Upper Saddle River, NJ, Prentice-Hall, 1997, p. 81.
} 
se retratan claramente en el último plano de la película: la sinecdótica mano muerta de Macario que intenta alcanzar el guajolote mitad carne, mitad esqueleto_-vida y muerte. ${ }^{51}$ (Véase el dibujo de este plano.)

"Adoptar es adaptar" asevera la folclorista Frenk. ${ }^{52}$ En la actualidad existen variantes documentadas de esta historia en vasco, gallego, ${ }^{53}$ catalán, finlandés, sueco, estonio, lituano, danés, lapón, noruego, escocés, irlandés, francés, holandés, flamenco, alemán, italiano, rumano, húngaro, checo, esloveno, serbocroata, polaco, ruso, griego, turco, hindi, en portugués en el Cabo Verde, y en español en España, México, la República Dominicana, ${ }^{54}$ la Argentina, Puerto Rico ${ }^{55}$ y hasta la comunidad chicana de California. ${ }^{56}$ Macario, nexo del folclore asiático, europeo y americano como espero haber demostrado, es el broche de oro cinematográfico de una tradición que ha dado la vuelta al mundo, vinculando a todos los transmisores de la tradición oral que han vivido y por vivir. Y como Macario descubrió, igual que Segismundo, "El hacer bien ni aun en sueños se pierde".

Recibido: agosto de 2006 Aceptado: octubre de 2006

${ }^{51}$ Este plano sólo dura unos segundos, por lo cual muchos críticos lo recuerdan mal, afirmando que Macario se comió el guajolote o que el pavo sigue entero. Si fijamos la imagen, se ve claramente la mano de Macario (sinécdoque), la mitad que le corresponde entera, y la mitad que le corresponde a la Muerte hecha esqueleto.

${ }^{52}$ Margit Frenk, Entre folklore y literatura, 2a ed., México, Colmex, 1984, p. 21.

${ }^{53}$ Julio Camarena y Maxime Chevalier, Catálogo tipológico del evento folklórico español. Cuentos maravillosos, Madrid, Gredos, 1995, p. 181.

${ }^{54}$ Stith Thompson, The Folkltale, Nueva York, Holt, Rinehart and Winston, 1946, p. 124.

${ }^{55}$ Stanley L. Robe, Antología del saber popular. A selection from various Genres of Mexican Folklore Across Borders, Monograph, núm. 2, Los Ángeles, UCLA, Chicano Studies Center, 1971, p. 40.

${ }^{56}$ Ibid., pp. 3-4, y Elaine K. Millar, Mexican Folk. Narrative from the Los Angeles Area, Austin, University of Texas Press, 1973, pp. 222-228. 


\begin{tabular}{|c|c|c|c|c|c|c|c|}
\hline & $\begin{array}{l}\text { PURANA } \\
\text { (LEYENDA) } \\
\text { HINDÚ } \\
\text { RELIGIOSO } \\
\text { POPULAR }\end{array}$ & $\begin{array}{l}\text { CUENTO } \\
\text { GRIEGO } \\
\text { FOLCLÓ- } \\
\text { RICO } \\
\text { (RECOGIDO } \\
\text { POR } \\
\text { LAWSON EN } \\
\text { 1964) }\end{array}$ & $\begin{array}{l}\text { CUENTO } \\
\text { ALEMAN } \\
\text { FOLCLÓ- } \\
\text { RICO } \\
\text { (NÚM. } 42 \text { Y } \\
\text { 44) }\end{array}$ & $\begin{array}{l}\text { CUENTO } \\
\text { MEXI- } \\
\text { CANO } \\
\text { FOLCLÓ- } \\
\text { RICO } \\
\text { (VARIAN- } \\
\text { TES } \\
\text { ORALES } \\
\text { RECOGIDAS } \\
\text { EN JALISCO } \\
\text { Y } \\
\text { VERACRUZ) }\end{array}$ & $\begin{array}{l}\text { CUENTO DE } \\
\text { B. TRAVEN } \\
\text { (YANQUI } \\
\text { ALEMÁN } \\
\text { RADICADO } \\
\text { EN MÉXICO } \\
\text { 1882-1969) }\end{array}$ & $\begin{array}{l}\text { GUION DE } \\
\text { MACARIO } \\
\text { DE EMILIO } \\
\text { CARBA- } \\
\text { LLIDO, } \\
\text { ROBERTO } \\
\text { GAVALDON } \\
\text { Y PEDRO DE } \\
\text { URDEMA- } \\
\text { LES (FOL- } \\
\text { CLORE/;B. } \\
\text { TRAVEN?) }\end{array}$ & $\begin{array}{l}\text { MACARIO } \\
\text { (PELICULA } \\
\text { DIR. POR } \\
\text { ROBERTO } \\
\text { GABALDÓN } \\
\text { (1909-1986); } \\
\text { DIR. DE } \\
\text { FOTOGRA- } \\
\text { FÍA } \\
\text { GABRIEL } \\
\text { FIGUEROA } \\
\text { (1907-1997) }\end{array}$ \\
\hline Origen & $\begin{array}{l}\text { Tradición oral } \\
\text { en sánscrito - } \\
500 \text { años a.c. } \\
\text { para explicar } \\
\text { en términos } \\
\text { populares } \\
\text { conceptos } \\
\text { religiosos del } \\
\text { hinduismo. }\end{array}$ & $\begin{array}{l}\text { Época } \\
\text { posterior a la } \\
\text { clásica } \\
\text { (Blum) } \\
\text { Los griegos } \\
\text { conquistaron } \\
\text { el Punjab en la } \\
\text { antigüedad. } \\
\text { (Otra ruta: } \\
\text { trad. del } \\
\text { sánscrito al } \\
\text { persa, del } \\
\text { persa al árabe, } \\
\text { del árabe al } \\
\text { latín, del latín } \\
\text { a otras lenguas } \\
\text { en el siglo } \\
\text { XIII). }\end{array}$ & $\begin{array}{l}\text { Data de } 1300 \text { o } \\
\text { antes } \\
\text { (Thompson); } \\
\text { recopilación } \\
\text { de los Hmnos } \\
\text { Grimm } \\
\text { publicada en } \\
1819 . \\
\text { Traducción } \\
\text { posterior al } \\
\text { español y a } \\
\text { otras lenguas. }\end{array}$ & $\begin{array}{l}\text { Traducción al } \\
\text { español a } \\
\text { mediados del } \\
\text { XIX en España. } \\
\text { Tradición oral: } \\
\text { Fecha más } \\
\text { temprana: } \\
1943 \\
\text { (Wheeler). } \\
\text { Los estudios } \\
\text { folclóricos no } \\
\text { comienzan en } \\
\text { México hasta } \\
\text { 1896. }\end{array}$ & $\begin{array}{l}\text { "Der dritte } \\
\text { Gast" se } \\
\text { publica en } \\
1950 \text { en } \\
\text { alemán; } \\
\text { The Third } \\
\text { Guest" se } \\
\text { publica en } \\
1953 \text { en inglés; } \\
\text { "Macario" se } \\
\text { publica en } \\
\text { 1956 en } \\
\text { español } \\
\text { (traducción de } \\
\text { Rosa Elena } \\
\text { Luján, esposa } \\
\text { de BT). }\end{array}$ & $\begin{array}{l}\text { 1958-1959 } \\
\text { "Pedro de } \\
\text { Urdemales" es } \\
\text { una figura } \\
\text { folclórica. O } \\
\text { indica la } \\
\text { fuente } \\
\text { folclórica o } \\
\text { encubre el } \\
\text { nombre de B. } \\
\text { Traven. Rosa } \\
\text { Elena Luján } \\
\text { dio permiso } \\
\text { para la } \\
\text { publicación } \\
\text { del guión. }\end{array}$ & $\begin{array}{l}\text { Rodaje en } 5 \\
\text { semanas en } \\
1959 \text {; estreno } \\
\text { en } 1960 .\end{array}$ \\
\hline Protagonista & $\begin{array}{l}\text { Narada } \\
\text { "el que da } \\
\text { agua"; médico; } \\
\text { músico; } \\
\text { discípulo de } \\
\text { Vishnu } \\
\text { (Krishna); } \\
\text { filósofo que se } \\
\text { encarna } \\
\text { repetidas veces } \\
\text { a lo largo de } \\
\text { los siglos; } \\
\text { hombre } \\
\text { genérico. }\end{array}$ & $\begin{array}{l}\text { Hombre }> \\
\text { Médico }\end{array}$ & $\begin{array}{l}\text { Hombre > } \\
\text { Médico }\end{array}$ & $\begin{array}{l}\text { El hartón o el } \\
\text { hambriento o } \\
\text { Juan Holgado } \\
> \\
\text { Curandero }\end{array}$ & $\begin{array}{l}\text { Macario } \\
\text { Leñador> } \\
\text { Curandero }\end{array}$ & $\begin{array}{l}\text { Macario } \\
\text { Leñador > } \\
\text { Curandero }\end{array}$ & $\begin{array}{l}\text { Macario } \\
\text { Leñador> } \\
\text { Curandero }\end{array}$ \\
\hline $\begin{array}{l}\text { Personajes } \\
\text { secundarios: } \\
\text { a. Familia }\end{array}$ & $\begin{array}{l}\text { Esposa e } \\
\text { hijo(s) }\end{array}$ & $\begin{array}{l}\text { Esposa e hijos, } \\
\text { siete de los } \\
\text { cuales mueren. }\end{array}$ & $\begin{array}{l}\text { Esposa y } 12 \\
\text { hijos }\end{array}$ & $\begin{array}{l}\text { Esposa e hijos } \\
\text { En una versión } \\
\text { espera casarse } \\
\text { con la hija del } \\
\text { rey. }\end{array}$ & $\begin{array}{l}\text { "La mujer de } \\
\text { los ojos } \\
\text { tristes", esposa } \\
\text { y } 11 \text { hijos. }\end{array}$ & $\begin{array}{l}\text { Esposa y } 5 \\
\text { hijos. }\end{array}$ & $\begin{array}{l}\text { Esposa y } 5 \\
\text { hijos ( } 3 \\
\text { varones y } 2 \\
\text { mujeres). }\end{array}$ \\
\hline b. Otros & - & - & - & - & - & $\begin{array}{l}\text { Cerero, } \\
\text { panadero, D. } \\
\text { Ramiro; } \\
\text { esposa de D. } \\
\text { Ramiro; criada } \\
\text { de D. Ramiro; } \\
\text { vecinos; cura; } \\
\text { inquisidores; } \\
\text { enfermos; } \\
\text { verdugo; } \\
\text { prisioneros; } \\
\text { soldados. }\end{array}$ & $\begin{array}{l}\text { Cerero, } \\
\text { panadero, D. } \\
\text { Ramiro; } \\
\text { esposa de D. } \\
\text { Ramiro; criada } \\
\text { de D. Ramiro; } \\
\text { vecinos; cura; } \\
\text { inquisidores; } \\
\text { enfermos; } \\
\text { verdugo; } \\
\text { prisioneros; } \\
\text { soldados. }\end{array}$ \\
\hline
\end{tabular}

Nancy J. Membrez. "El peón y la Muerte" 


\begin{tabular}{|c|c|c|c|c|c|c|c|}
\hline $\begin{array}{l}\text { Espacio } \\
\text { temporal }\end{array}$ & $\begin{array}{l}\text { India: } \\
\text { Atemporal }\end{array}$ & $\begin{array}{l}\text { Grecia: } \\
\text { Atemporal }\end{array}$ & $\begin{array}{l}\text { Alemania: } \\
\text { Edad media }\end{array}$ & $\begin{array}{l}\text { México: } \\
\text { Colonial o } \\
\text { atemporal }\end{array}$ & $\begin{array}{l}\text { México: } \\
\text { Siglo de oro } \\
\text { colonial }\end{array}$ & $\begin{array}{l}\text { México: } \\
\text { Siglo de oro } \\
\text { colonial }\end{array}$ & $\begin{array}{l}\text { México: } \\
\text { Siglo XVIII } \\
\text { colonial } \\
\text { (pelucas } \\
\text { blancas y } \\
\text { origen del } \\
\text { corrido). }\end{array}$ \\
\hline $\begin{array}{l}\text { Encuentro } \\
\text { con un } \\
\text { antagonista } \\
\text { divino } \\
\text { (motivo } \\
\text { folclórico } \\
\text { 332.1) }\end{array}$ & $\begin{array}{l}\text { Narada y } \\
\text { Vishnu, } \\
\text { dios védico, } \\
\text { uno de los } \\
\text { dioses de la } \\
\text { trinidad hindú, } \\
\text { señor del } \\
\text { tiempo, que a } \\
\text { veces se retrata } \\
\text { con tres caras } \\
\text { (mirando al } \\
\text { pasado, } \\
\text { presente y } \\
\text { futuro). }\end{array}$ & $\begin{array}{l}\text { Hombre y } \\
\text { Caronte } \\
\text { Personifica- } \\
\text { ción masculina } \\
\text { de la muerte } \\
\text { desde la época } \\
\text { pos-clásica } \\
\text { hasta hoy; } \\
\text { Caronte no } \\
\text { sólo aparece } \\
\text { en su barca } \\
\text { sino que anda } \\
\text { o cabalga por } \\
\text { el mundo } \\
\text { recogiendo } \\
\text { almas. }\end{array}$ & $\begin{array}{l}\text { Hombre y der } \\
\text { Tod (la } \\
\text { Muerte) (44)- } \\
\text { personifica- } \\
\text { ción masculina } \\
\text { el Mal pálido, } \\
\text { segador de } \\
\text { almas. } \\
\text { El Sr. padrino } \\
\text { (42) es el } \\
\text { Diablo. } \\
\text { Traducción de } \\
\text { la recopilación } \\
\text { de los Grimm } \\
\text { a las lenguas } \\
\text { romances: la } \\
\text { muerte } \\
\text { femenina. }\end{array}$ & $\begin{array}{l}\text { Hombre y } \\
\text { La muerte: } \\
\text { personifica- } \\
\text { ción femenina. } \\
\text { ( } 332.1 \mathrm{La} \\
\text { muerte } \\
\text { madrina). }\end{array}$ & $\begin{array}{l}\text { Macario y el } \\
\text { Diablo (charro } \\
\text { a caballo), } \\
\text { Dios } \\
\text { peregrino, y la } \\
\text { Muerte, } \\
\text { personifica- } \\
\text { ción masculina } \\
\text { (der Tod) } \\
\text { vestido de } \\
\text { peón; } \\
\text { eufemismos } \\
\text { para evitar el } \\
\text { dilema } \\
\text { lingüístico: } \\
\text { el visitante, el } \\
\text { intruso, el } \\
\text { caminante, el } \\
\text { forastero, el } \\
\text { compadre, el } \\
\text { convidado. } \\
\text { Lleva } \\
\text { cronómetro } \\
\text { inglés. }\end{array}$ & $\begin{array}{l}\text { Macario y } \\
\text { el Diablo } \\
\text { (charro a } \\
\text { caballo), Dios } \\
\text { peregrino, } \\
\text { y la Muerte } \\
\text { (personifica- } \\
\text { ción masculina } \\
\text { vestida de } \\
\text { militar). }\end{array}$ & 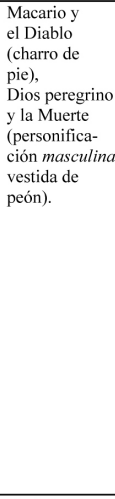 \\
\hline $\begin{array}{l}\text { Petición/ } \\
\text { regalo } \\
\text { (motivo } \\
\text { folclórico } \\
\text { 332.2) }\end{array}$ & $\begin{array}{l}\text { Un vaso de } \\
\text { agua/el velo de } \\
\text { "maya". }\end{array}$ & $\begin{array}{l}\text { La habilidad } \\
\text { de ver la } \\
\text { Muerte y } \\
\text { pronosticar la } \\
\text { muerte o la } \\
\text { supervivencia } \\
\text { de la víctima. } \\
\text { Variante: La } \\
\text { Muerte le pide } \\
\text { un cordero y al } \\
\text { fin y al cabo el } \\
\text { pastor se lo da. }\end{array}$ & $\begin{array}{l}\text { Raíz; agua } \\
\text { milagrosa; } \\
\text { La habilidad } \\
\text { de ver la } \\
\text { Muerte y } \\
\text { pronosticar la } \\
\text { muerte o la } \\
\text { supervivencia } \\
\text { de la víctima. }\end{array}$ & $\begin{array}{l}\text { Liebre o } \\
\text { gallina; } \\
\text { Agua } \\
\text { milagrosa; } \\
\text { La habilidad } \\
\text { de ver apare- } \\
\text { cer a la Muerte } \\
\text { para } \\
\text { pronosticar la } \\
\text { muerte o la } \\
\text { supervivencia } \\
\text { de la víctima. }\end{array}$ & $\begin{array}{l}\text { Guajolote; } \\
\text { agua } \\
\text { milagrosa; } \\
\text { La habilidad } \\
\text { de ver apare- } \\
\text { ce r a la } \\
\text { Muerte para } \\
\text { pronosticar la } \\
\text { muerte de la } \\
\text { víctima. }\end{array}$ & $\begin{array}{l}\text { Guajolote/ } \\
\text { Agua } \\
\text { milagrosa; La } \\
\text { habilidad de } \\
\text { ver aparece a } \\
\text { la Muerte para } \\
\text { pronosticar la } \\
\text { muerte de la } \\
\text { víctima, }\end{array}$ & $\begin{array}{l}\text { Guajolote/ } \\
\text { Agua } \\
\text { milagrosa; La } \\
\text { habilidad de } \\
\text { ver aparece a } \\
\text { la Muerte para } \\
\text { pronosticar la } \\
\text { muerte de la } \\
\text { víctima. }\end{array}$ \\
\hline $\begin{array}{l}\text { Juego de la } \\
\text { cama del } \\
\text { enfermo } \\
\text { (motivo } \\
\text { folclórico } \\
\text { 332.3) }\end{array}$ & - & $\begin{array}{l}\text { A la cabecera, } \\
\text { vida; a los } \\
\text { pies, muerte. } \\
\text { Variante: La } \\
\text { esposa hace } \\
\text { girar la cama } \\
\text { para salvar a } \\
\text { su esposo. }\end{array}$ & $\begin{array}{l}\text { A la cabecera, } \\
\text { vida; a los } \\
\text { pies, muerte. } \\
\text { El hombre } \\
\text { hace girar la } \\
\text { cama para } \\
\text { salvar a la } \\
\text { princesa. }\end{array}$ & $\begin{array}{l}\text { A la cabecera, } \\
\text { muerte; a los } \\
\text { pies, vida. } \\
\text { El hombre } \\
\text { hace girar la } \\
\text { cama para } \\
\text { salvar al rey. }\end{array}$ & $\begin{array}{l}\text { A la cabecera, } \\
\text { muerte; a los } \\
\text { pies, vida. } \\
\text { El hombre } \\
\text { hace girar la } \\
\text { cama para } \\
\text { salvar al hijo } \\
\text { del virrey. }\end{array}$ & $\begin{array}{l}\text { A la cabecera, } \\
\text { muerte; a los } \\
\text { pies, vida. } \\
\text { El hombre } \\
\text { hace girar la } \\
\text { cama para } \\
\text { salvar al hijo } \\
\text { del virrey. }\end{array}$ & $\begin{array}{l}\text { A la cabecera, } \\
\text { muerte; a los } \\
\text { pies, vida. } \\
\text { El hombre } \\
\text { hace girar la } \\
\text { cama para } \\
\text { salvar al hijo } \\
\text { del virrey. }\end{array}$ \\
\hline $\begin{array}{l}\begin{array}{l}\text { Cueva } \\
\text { (motivo }\end{array} \\
\text { folclórico } \\
\text { 332.4) }\end{array}$ & - & $\begin{array}{l}\text { Cueva de velas } \\
\text { vela = hombre } \\
\text { (Blum). } \\
\text { Variante: Casa } \\
\text { llena de } \\
\text { lámparas. }\end{array}$ & $\begin{array}{l}\text { Cueva de } \\
\text { velas. }\end{array}$ & $\begin{array}{l}\text { A veces: la } \\
\text { cueva de velas. }\end{array}$ & $\begin{array}{l}\quad \text { - } \\
\text { (Brilla por su } \\
\text { ausencia). }\end{array}$ & $\begin{array}{l}\text { Cueva de } \\
\text { velas. }\end{array}$ & $\begin{array}{l}\text { Cueva de } \\
\text { velas. }\end{array}$ \\
\hline
\end{tabular}

Nancy J. Membrez. "El peón y la Muerte" 


\begin{tabular}{|c|c|c|c|c|c|c|c|}
\hline $\begin{array}{l}\text { Error o } \\
\text { pecado } \\
\text { (motivo } \\
\text { folclórico) }\end{array}$ & $\begin{array}{l}\text { No } \\
\text { comprender el } \\
\text { poder del velo } \\
\text { de "maya"; } \\
\text { ingenuidad; en } \\
\text { el contexto } \\
\text { hindú, más } \\
\text { bien un } \\
\text { "error". }\end{array}$ & $\begin{array}{l}\text { Retar a } \\
\text { Caronte } \\
\text { (Juego de la } \\
\text { cama para } \\
\text { salvarse a sí } \\
\text { mismo). }\end{array}$ & $\begin{array}{l}\text { Retar a la } \\
\text { Muerte } \\
\text { padrina. }\end{array}$ & $\begin{array}{l}\text { Retar a la } \\
\text { Muerte } \\
\text { madrina con } \\
\text { una curación } \\
\text { indebida; en } \\
\text { otras variantes, } \\
\text { no compartir la } \\
\text { gallina con sus } \\
\text { hijos y esposa. }\end{array}$ & $\begin{array}{l}\text { Retar a la } \\
\text { Muerte } \\
\text { padrina } \\
\text { (juego de } \\
\text { cama). }\end{array}$ & $\begin{array}{l}\text { Retar a la } \\
\text { Muerte } \\
\text { padrina; } \\
\text { haberse } \\
\text { enriquecido en } \\
\text { lugar de seguir } \\
\text { humilde } \\
\text { (camino de } \\
\text { Jesús). }\end{array}$ & $\begin{array}{l}\text { Retar a la } \\
\text { Muerte; } \\
\text { padrina; } \\
\text { haberse } \\
\text { enriquecido en } \\
\text { lugar de seguir } \\
\text { humilde } \\
\text { (camino de } \\
\text { Jesús). }\end{array}$ \\
\hline b. & $\begin{array}{l}\text { Vishnu le } \\
\text { recuerda el } \\
\text { vaso de agua. }\end{array}$ & $\begin{array}{l}\text { Después de los } \\
\text { dos años } \\
\text { concedidos, } \\
\text { Caronte se } \\
\text { lleva al } \\
\text { médico, su } \\
\text { compadre. } \\
\text { Variante: } \\
\text { Reconoce que } \\
\text { no ha sido un } \\
\text { sueño. }\end{array}$ & $\begin{array}{l}\text { La muerte } \\
\text { engaña a su } \\
\text { ahijado y } \\
\text { extingue la } \\
\text { vela de éste. }\end{array}$ & $\begin{array}{l}\text { El hartón cura } \\
\text { al rey, la } \\
\text { Muerte se } \\
\text { lleva al } \\
\text { médico, pero } \\
\text { su familia será } \\
\text { rica. }\end{array}$ & $\begin{array}{l}\text { Para que el } \\
\text { virrey no le } \\
\text { entregue a la } \\
\text { Inqusición, la } \\
\text { Muerte le } \\
\text { devuelve al } \\
\text { bosque donde } \\
\text { Macario } \\
\text { muere. }\end{array}$ & $\begin{array}{l}\text { Macario muere } \\
\text { con la vela en } \\
\text { la mano. }\end{array}$ & $\begin{array}{l}\text { Macario } \\
\text { intenta } \\
\text { alcanzar el } \\
\text { guajolote } \\
\text { medio comido } \\
\text { y muere. } \\
\text { (Ver imagen } \\
\text { adjunta). }\end{array}$ \\
\hline b. Guajolote & - & - & - & - & $\begin{array}{l}\text { La esposa } \\
\text { ahorra durante } \\
\text { tres años para } \\
\text { poder regalarle } \\
\text { el guajolote a } \\
\text { su esposo. }\end{array}$ & $\begin{array}{l}\text { La esposa roba } \\
\text { el guajolote. }\end{array}$ & $\begin{array}{l}\text { La esposa roba } \\
\text { el guajolote. }\end{array}$ \\
\hline c. Fantoches & - & - & - & - & - & $\begin{array}{l}\text { Pesadilla de } \\
\text { Macario: } \\
\text { Dibujos } \\
\text { animados con } \\
\text { sobre- } \\
\text { impresiones de } \\
\text { calaveras y } \\
\text { esqueletos. }\end{array}$ & $\begin{array}{l}\text { Pesadilla de } \\
\text { Macario: } \\
\text { Marionetas de } \\
\text { esqueletos que } \\
\text { recrean el } \\
\text { "Fandango", } \\
\text { grabado de } \\
\text { Posada; sobre- } \\
\text { impresión de } \\
\text { Macario como }\end{array}$ \\
\hline
\end{tabular}

Nancy J. Membrez. "El peón y la Muerte” 


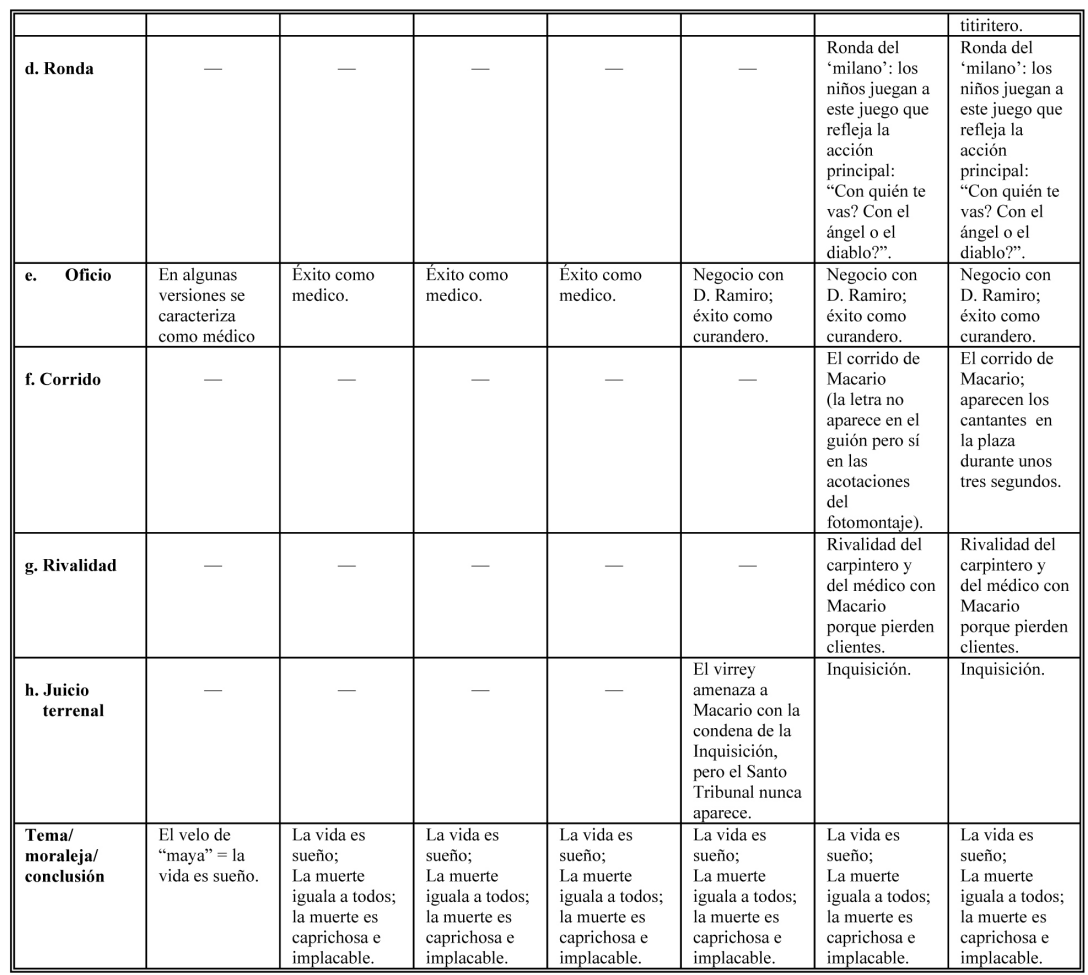

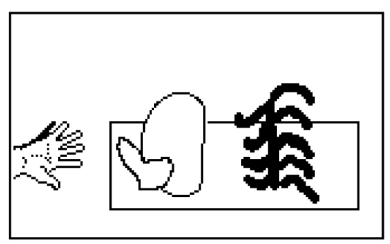

Último plano de Macario

Nancy J. Membrez. "El peón y la Muerte" 


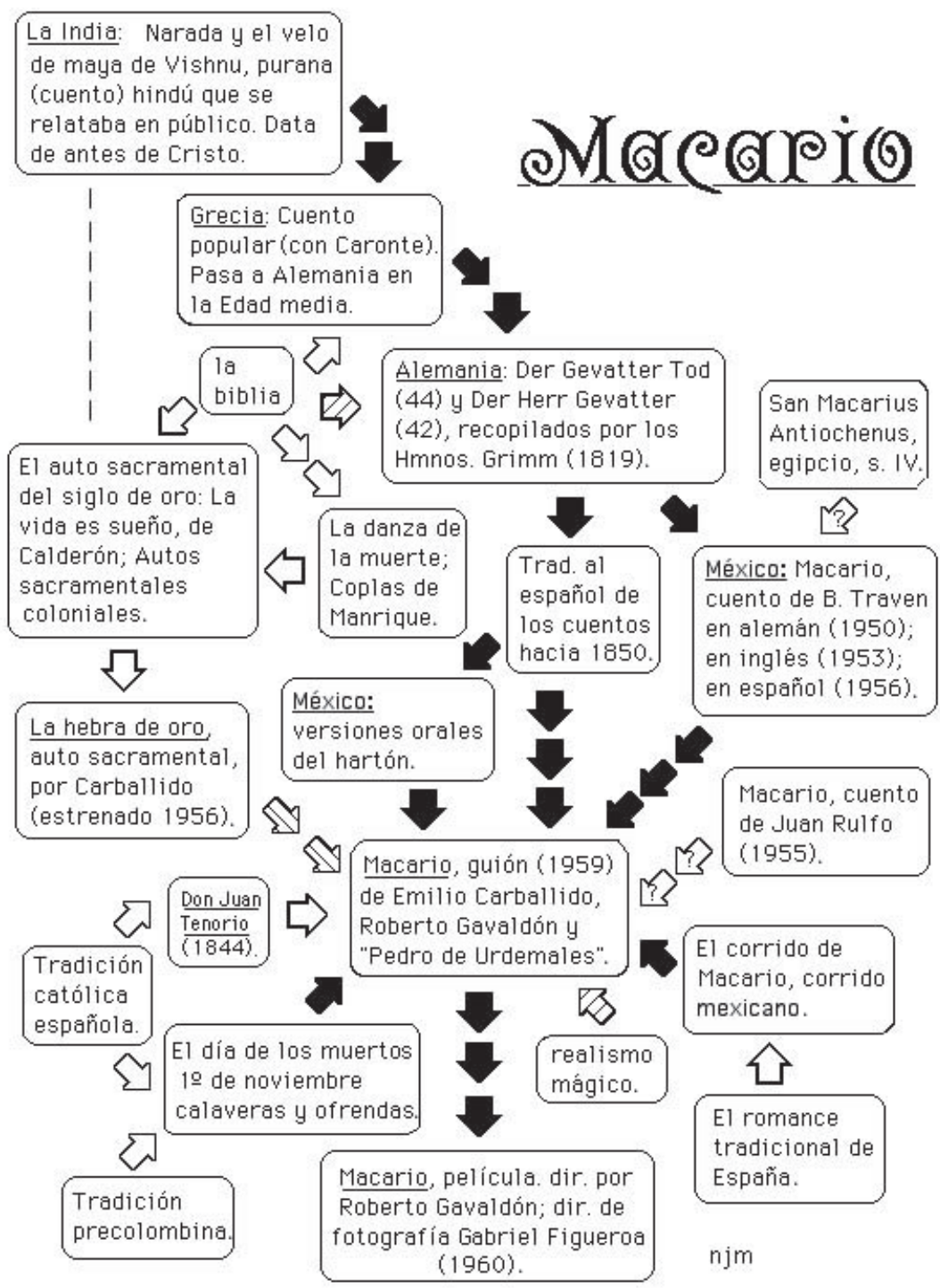




\section{OBRAS CITADAS}

An OCCuRRence at OWL CREEK Bridge (1962). Cortometraje.

AnZUREs Rionda, María, Lengua y cultura náhuatl, México, Ediciones Contraste, 1996.

Arnold, Heinz Ludwig, “B. Traven”, Text + Kritik, núm. 102, april, 1989. BALl, Thomas, "Vishnu's Maya: Filming a Legend", Wooster Alumni Magazine 91.4, mayo, 1977, pp. 2-4.

Barrow, Leo L. y Robert H. Hammond, Macario. A Textbook Based on a Filmscript by B. Traven [¿sic?], Riverside, CA, J.B., Blanchard Press, 1973.

Baumann, Michael L, B. Traven: An Introduction, Albuquerque, University of New Mexico Press, 1976.

Bill and Ted's Bogus Journey (1991), Dir. Pete Hewitt, Guión de Chris Matheson y Ed Solomon.

Blum, Richard y Eva, The Dangerous Hour: The Lore of Crisis and Mystery in Rural Greece, Londres, Chatto and Loindus, 1970.

Borges, Jorge Luis, "El milagro secreto", Ficciones, Buenos Aires, Emecé, 1956.

Brodman, Barbara L. C., The Mexican Cult of Death in Myth and Literature, Gainesville, FL, University of Florida, 1976.

Calderón de la BARCA, Pedro, La vida es sueño. El alcalde de Zalamea, $4^{\mathrm{a}}$ ed., ed. de Augusto Cortina. Clásicos castellanos, Madrid, Espasa-Calpe, 1968.

Camarena, Julio y Maxime Chevalier, Catálogo tipológico del cuento folklórico español. Cuentos maravillosos, Madrid, Gredos, 1995.

CAmpbell, Joseph, “Epílogo a los Grimm's Fairy Tales”, Nueva York, Pantheon Books, 1944.

Carballido, Emilio, La hebra de oro. Auto sacramental, México, Imprenta Universitaria, 1957.

CAstro, AmÉrico, "La leyenda de Don Juan en la literatura española", en Gregorio Marañón, Cinco ensayos sobre Don Juan. (Del Congreso sobre el tema, 1928), Valencia, Editorial "Esperia”, ¿1930? 
Cocchiara, Giuseppe, The History of Folklore in Europe, trad. de John

N. McDaniel, Filadelfia, Institute for the Study of Human Issues, 1981 [1952 c en italiano].

Death TAKes a Holiday (1934), Dir. Michael Leisen, Adapt. de Walter

Ferris basada en una pieza de Alberto Casella.

EL SÉPTIMO SELLO (1956), Dir. y guión de Ingmar Berman.

Ellis, John, One Fairy Story Too Many, Chicago, University of Chicago, 1983.

Espina, ConchA, "El Mal pálido [poesía]”, La Esfera, núm. 12.595, 30 de mayo, 1925 [16].

FrenK, MARgit, Entre folklore y literatura, $2^{\mathrm{a}}$ ed., México, Colmex, 1984. García Riera, Emilio, Historia documental del cine mexicano, vol. 7, México, Era, 1975.

Y FERNANDO MACOTELA, La guía del cine mexicano de la pantalla grande a la televisión 1919-1984, México, Editorial Patria, 1984. GoldBerg, HARriet, Motif-Index of Medieval Spanish Folk Narratives,

Tempe, AZ, Medieval and Renaissance Texts and Studies, Arizona State University, 1998.

GoudriaAn, Teun, Maya Divine and Human. A Study of Magic and Its Religious Foundations in Sanskrit Texts, with Particular Attention to a Fragment of Vishnu's Maya Preserved in Bali, Dahli, Motilal Banarsidass, Indological Publishers and Bookseller, 1978.

Grimm, JACOB Y Wilhelm, The Complete Grimm's Fairy Tales, Nueva York, Pantheon Books, 1944.

, Cuentos completos, trad. directa del alemán de Francisco

Payrols, rev. y pról. de Eduardo Valentí, Barcelona, Editorial Labor, 1955 (Sucursal en la ciudad de México).

, Kinder- und Hausmärchen, München, Winkler-Verlag, 1973 [Edición de 1819].

Ground Hog DaY (1993), Dir. Harold Ramis, Guión de Danny Rubin y Harold Ramis.

GuthKe, KARL. S., “Traven's 'Macario’ zwischen indianischer Folklore und den Märchen der Brüder Grimm", Zeitschrift für deutsche Phi- 
lologie, núm. 114.2, 1995, pp. 259-263.

Hamilton, Edith, Mythology, Boston, Little, Brown and Co., 1942.

Hastings, Selina [adapt.], The Man Who Wanted to Live Forever, ilus. de Reg Cartwright, Londres, Walker Books, 1988.

IsAac, AlBerto, Conversaciones con Gabriel Figueroa, Guadalajara, Universidad de Guadalajara, 1993.

Last Action Hero (1993), Dir. John McTiernan, Guión de Shane Black y David Arnott.

Lawson, John CuthBert, Modern Greek Folklore and Ancient Greek Religion. A Study in Survivals, Nueva York, University Books, 1964. López Aranda, Susana, El cine de Ignacio López Tarso, México, Universidad de Guadalajara, 1997.

MACARIO (1960), Dir. Roberto Gavaldón, Guión de Roberto Gavaldón, Emilio Carballido y "Pedro de Urdemalas" [¿B. Traven?].

MachineK, AngelikA, "Vita B. Traven - B. Traven Bibliographie", Text + Kritik, núm. 102, abril, 1989.

Maugham, Somerset, Appointment in Samarra, Nueva York, Modern Library, 1953.

MEET JOE BLACK (1998), Dir. Martin Brest, Guión de Ron Osborne, Jeff Reno, Kevin Wade y Bo Goodman, adapt. basada en Death Takes a Holiday y la pieza original de Casella.

Megas, George A. [ed.], Folktales of Greece, trad. de Helen Colaclides, Chicago, University of Chicago Press, 1970.

Miller, Charles, "Introduction" a B. Traven, The Night Visitor and Other Stories, Nueva York, Hill and Wang, 1966.

Miller, Elaine K., Mexican Folk Narrative from the Los Angeles Area, Austin, University of Texas Press, 1973.

Molina, FRAY AlONSO DE, Vocabulario en lengua castellana y mexicana y mexicana y castellana, 2a ed., México, Porrúa, 1977 [c 1555-1571]. ON BORROWED TIME (1939), Dir. Harold S. Bucquet, Guión de Alice D.G., Miller, Frank O’Neill y Claudine West.

PAz, OCTAVIO, "Todos santos, día de muertos", en El laberinto de la soledad, México, FCE, 1950. 
Paranaguá, Paulo Antonio [recop.], Mexican Cinema, trad. de Ana M. López, Londres, British Film Institute, 1995.

Peden, Margaret Sayers, Emilio Carballido, Boston, Twayne Publishers, 1980.

Posada, José Guadalupe, Posada's Popular Mexican Prints: 273 Cuts, Nueva York, Dover Publications, 1972.

Propp, Vladmir, Morphology of the Folktale, $2^{\mathrm{a}}$ ed., Austin, University of Texas, 1968 [c 1928 en ruso].

RedDI, M. RAJA, Narada in Literatura, Tirupati, India, Adyar Students Xerox Centre, 1995.

Robe, Stanley L., Antología del saber popular. A Selection from Various Genres of Mexican Folklore Across Borders, Monograph, núm. 2, junio, 1971, Los Ángeles, UCLA Chicano Studies Center, 1971. , Mexican Tales and Legends from Veracruz, Berkeley, University of California Press, 1971.

Richter, ARMin, “B. Traven (1882-1969)”, Texto Crítico, núm. 15 octubre-diciembre, 1979, pp. 165-179.

Rulfo, JuAn, El llano en llamas, México, FCE, 1953.

"SAINT MaCARIUS THE GREAT", Catholic Information Network, Internet (2000).

Shastri, Prabhu Dutt, The Doctrine of Maya in the Philosophy of the Vedanta, Londres, Luzac and Co., 1911.

Simmons, Merle, The Mexican Corrido as a Source for Interpretive Study of Modern Mexico (1870-1950), Bloomington, Indiana University Press, 1957.

SkinNer, Eugene, "Carballido: temática y forma de tres autos", Latin American Theater Review, núm. 3.1, 1969, pp. 37-47.

THE MATRIX (1999), Guión y dirección de Larry y Andy Wachowski. Thompson, Stith, The Folktale, Nueva York, Holt, Rinehart and Winston, 1946.

, The Types of the Folktale. A Classification and Bibliography. Antti Aarne's Verzeichnis der Märchentypen, trad. y aum. de Stith Thompson, $2^{a}$ ed. revisada, Helsinki, Suomalainen Tiedeakatemia, 1961. 
Tomlinson, Janis, From El Greco to Goya. Painting in Spain (15611828), Upper Saddle River, NJ, Prentice-Hall, 1997.

Traven, B., "Macario", Versión alemana: "Der dritte Gast” (1950). Versión inglesa: "The Third Guest" (1954). Reimpreso bajo el título "Macario" en The Night Visitor and Other Stories, Nueva York, Hill and Wang, 1966. Versión mexicana escolar en español. Edición a cargo de Sheilah R. Wilson, trad. de Rosa Elena Luján, Boston, Houghton Mifflin, 1960.

, El tesoro de la Sierra Madre, ed. de Mario B. Rodríguez, Nueva York, Appleton-Century-Crofts, 1963.

, The Treasure of the Sierra Madre, Nueva York, Time Incorporated, 1963 [1935 c.].

Vasconcelos, José, Estudios indostánicos, $3^{\mathrm{a}}$ ed., México, Ediciones Botas, 1938.

Vélez, Joseph F., "Una entrevista con Emilio Carballido", Latin American Theater Review, núm. 7.1, 1973, pp. 17-24.

VERSÉNYI, ADAM, "Getting under the Aztec Skin: Evangelical Theatre in the New World”, New Theater Quarterly, núm. 5.19, 1989, pp. 217-226.

Wheeler, Howard T., Tales from Jalisco, México, Filadelfia, American Folklore Association, 1943.

Zavala, M. y A. Medina, Vocabulario español-maya, Mérida, Yucatán, 1975 [c 1898].

ZúÑIgA, ArIEL, “Roberto Gavaldón”, en Paulo Antonio Paranaguá, $M e$ xican Cinema, trad. de Ana M. López, Londres, British Film Institute, 1995.

, Vasos comunicantes en la obra de Roberto Gavaldón, México, El Equilibrista, 1990. 